Section Editor

Robert C. Griggs, MD
Editors' Note: Drs. Brenner, Calamante, and Gross, Neurology ${ }^{\circledR}$ Editor-in-Chief, discuss the ethical implications of the artistic interpretation of animal research. Teive and colleagues describe their experience with a patient with lipoid proteinosis to further stress the susceptibility of brain blood vessel to rupture in this disease.

Chafic Karam, $M D$, and Robert C. Griggs, $M D$

\section{MOUSE BRAIN KALEIDOSCOPE}

Steven R. Brenner, St. Louis: While this image is beautiful, ${ }^{1}$ it seems to have gone beyond the intended purpose of the original research on the mice. I understand publishing the original mouse brain image based on the striking images as an educational process and raising awareness of the experimental animals, technology, and the findings involved. However, arranging them in the kaleidoscope design appears to me to go beyond the original intent of the research and takes on the perspective of artistic expression.

I may be overly sensitive, however I want to raise awareness of experimental animals and the dependence we have on them for research in understanding and developing treatments for human diseases. Should the results of such animal research be used in artistic expression? The bioscience community accepts that animals should be used for research only within an ethical framework. ${ }^{2}$

\section{Author Response: Fernando Calamante, Melbourne:} I appreciate the comment by Dr. Brenner regarding the brain kaleidoscope image. ${ }^{1}$ Further to his comment, we would like to clarify that the image used to construct the kaleidoscope was from a dataset acquired for justifiable scientific purposes. ${ }^{3}$ The subsequent use of the image for artistic expression should not detract from the primary purpose of these data.

We would argue that medical research in general (not just animal research) should only be undertaken for good scientific reasons.

(C) 2013 American Academy of Neurology

1. Calamante F. Visions: Mouse Brain Kaleidoscope. Neurology 2012:79;1829.

2. Festing $\mathrm{S}$, Wilkinson $\mathrm{R}$, The ethics of animal research: talking point on the use of animals in scientific research. EMBO Rep 2007:8:526-530.
WriteClick: Editor's Choice

3. Calamante F, Tournier J-D, Kurniawan ND, et al. Superresolution track-density imaging studies of mouse brain: comparison to histology. NeuroImage 2012;59:286-296.

Editor's Note: Robert A. Gross, Rochester, NY: Dr. Brenner raises an important point about the ethical treatment of animals, a position with which we agree. As the text accompanying the image makes clear, this animal work was done to refine imaging techniques. The result, published elsewhere, had another benefit: it yielded beautiful images of the nervous system. Had the animal work been done solely for artistic purposes, one could raise ethical concerns; but providing a thought-provoking and esthetic image of the nervous system, using already-acquired material, seems felicitous and beneficial. The purpose of the occasional Visions section is to provide artistic images of a neurologic nature, for our edification.

\section{SPONTANEOUS INTRACEREBRAL HEMORRHAGE IN URBACH-WIETHE DISEASE}

Helio A. Teive, Curitiba; Eduardo Ruschel, Joinville; Renato P. Munhoz, Curitiba, Brazil: Messina et al. ${ }^{1}$ presented a 39-year-old woman with Urbach-Wiethe disease or lipoid proteinosis (LP) who developed right hemiparesis due to a left lenticular nucleus hemorrhage. The authors suggested that LP is associated with diffuse small-vessel disease. LP is a rare autosomal recessive disease due to mutations in the extracellular matrix protein 1 (ECM1) gene. ${ }^{2}$ ECM1, the protein mutated in LP, is expressed around the blood vessels and involved in angiogenesis. This abnormality could explain the susceptibility of brain blood vessel rupture. ${ }^{1}$ We published a case report of generalized dystonia and striatal calcifications in a patient with LP. ${ }^{3}$ Family history was positive for a 34-year-old sister diagnosed with LP who had epilepsy and mild mental retardation. ${ }^{3}$ This patient later developed a sudden right hemiplegia and brain MRI showed a massive hemorrhage in the left fronto-temporo-parietal lobe. The patient had neurosurgery and an extensive workup, including cerebral angiography, which was normal. This case report confirms the association of LP and brain hemorrhage, not only with small deep brain hemorrhage, but also with large brain hematoma.

C) 2013 American Academy of Neurology 
1. Messina MJ, Barbieri A, Scarlato M, et al. Spontaneous intracerebral hemorrhage in Urbach-Wiethe disease. Neurology 2012;79:1740-1741.

2. Hamada T, McLean WH, Ramsay M, et al. Lipoid proteinosis maps to $1 \mathrm{q} 21$ and is caused by mutations in the extracellular matrix protein 1 gene (ECM1). Hum Mol Genet 2002;11: 833-840.

3. Teive HAG, Pereira ER, Zavala JAA, et al. Generalized dystonia and striatal calcification with lipoid proteinosis. Neurology 2004;63:2168-2169.

Author disclosures are available upon request (journal@neurology.org). 


\section{Neurology}

\section{Spontaneous intracerebral hemorrhage in Urbach-Wiethe disease \\ Helio A. Teive, Eduardo Ruschel and Renato P. Munhoz \\ Neurology 2013;80;1720-1721 \\ DOI 10.1212/01.wnl.0000430259.37814.f5}

\section{This information is current as of April 29, 2013}

\section{Updated Information \&} Services

References

Permissions \& Licensing

Reprints including high resolution figures, can be found at: http://n.neurology.org/content/80/18/1720.2.full

This article cites 3 articles, 2 of which you can access for free at: http://n.neurology.org/content/80/18/1720.2.full\#ref-list-1

Information about reproducing this article in parts (figures,tables) or in its entirety can be found online at:

http://www.neurology.org/about/about_the_journal\#permissions

Information about ordering reprints can be found online:

http://n.neurology.org/subscribers/advertise

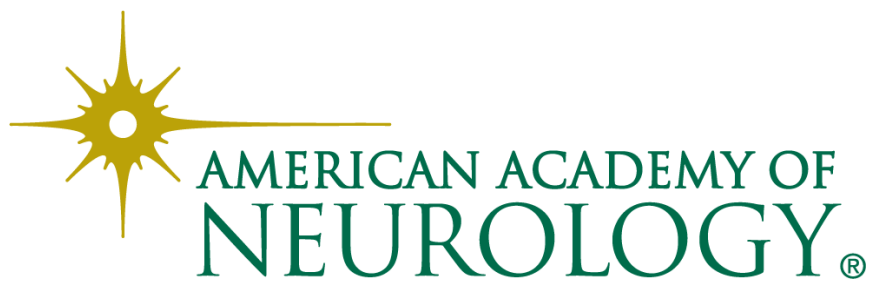

